\title{
What Is the Predictive Value of Animal Models for Vaccine Efficacy in Humans?
}

\section{The Importance of Bridging Studies and Species-Independent Correlates of Protection}

\author{
Hana Golding, Surender Khurana, and Marina Zaitseva \\ Division of Viral Products, Center for Biologics Evaluation and Research, Food and Drug Administration, \\ Silver Spring, Maryland 20993 \\ Correspondence: hana.golding@fda.hhs.gov
}

\begin{abstract}
Animal models have played a pivotal role in all stages of vaccine development. Their predictive value for vaccine effectiveness depends on the pathogen, the robustness of the animal challenge model, and the correlates of protection (if known). This article will cover key questions regarding bridging animal studies to efficacy trials in humans. Examples include human papillomavirus (HPV) vaccine in which animal protection after vaccination with heterologous prototype virus-like particles (VLPs) predicted successful efficacy trials in humans, and a recent approval of anthrax vaccine in accordance with the "Animal Rule." The establishment of animal models predictive of vaccine effectiveness in humans has been fraught with difficulties with low success rate to date. Challenges facing the use of animal models for vaccine development against Ebola and HIV will be discussed.
\end{abstract}

\section{GREAT DEBATES}

What are the most interesting topics likely to come up over dinner or drinks with your colleagues? Or, more importantly, what are the topics that don't come up because they are a little too controversial? In Immune Memory and Vaccines: Great Debates, Editors Rafi Ahmed and Shane Crotty have put together a collection of articles on such questions, written by thought leaders in these fields, with the freedom to talk about the issues as they see fit. This short, innovative format aims to bring a fresh perspective by encouraging authors to be opinionated, focus on what is most interesting and current, and avoid restating introductory material covered in many other reviews.

The Editors posed 13 interesting questions critical for our understanding of vaccines and immune memory to a broad group of experts in the field. In each case, several different perspectives are provided. Note that while each author knew that there were additional scientists addressing the same question, they did not know who these authors were, which ensured the independence of the opinions and perspectives expressed in each article. Our hope is that readers enjoy these articles and that they trigger many more conversations on these important topics.

Editors: Shane Crotty and Rafi Ahmed

Additional Perspectives on Immune Memory and Vaccines: Great Debates available at www.cshperspectives.org

Copyright (C) 2018 Cold Spring Harbor Laboratory Press; all rights reserved; doi: 10.1101/cshperspect.a028902 Cite this article as Cold Spring Harb Perspect Biol 2018;10:a028902 
H. Golding et al.

The he development of vaccines against human pathogens commonly includes animal studies at early stages of vaccine evaluation. Proofof-concept (POC) studies provide justification for further vaccine development and downselection of vaccine constructs and adjuvants. Entry into clinical phase 1 studies (to evaluate vaccine safety and obtain early immunological measurements) requires preclinical toxicity studies in animals conducted under "good laboratory practices" (GLPs) using the intended human vaccine. Phase 2 trials are conducted to optimize vaccine dose and vaccination schedule and to identify the most relevant immunological assays. Phase 1 and phase 2 trials are conducted in populations at low risk for infection and the number of participants is low $(\leq 300)$. Phase 3 trials are large-scale (in the thousands), conducted in high-risk populations (or geographical regions), and are powered to show reduction in infection rates or protection from severe disease in vaccinated compared with unvaccinated subjects. They are costly and may be conducted over several years in multiple locations.

In cases in which human efficacy studies are not ethical and field trials are not feasible, such as vaccines against diseases with sporadic or low incidence (e.g., Ebola), or agents that can be weaponized (e.g., anthrax), data from a wellestablished animal challenge model could complement the human safety and immunogenicity trials and provide a basis for vaccine approval under the Food and Drug Administration (FDA) "Animal Rule" (FDA 21CFR601.90) (Burns 2012).

The design and usage of animal studies to predict vaccine effectiveness in humans have been challenging. This review will focus on animal vaccine studies that include homologous or heterologous challenge strains with outcomes that closely mimic human infections and are likely to be predictive of vaccine effectiveness.

\section{PROOF-OF-CONCEPT STUDIES}

POC studies are often conducted in small animal species (i.e., inbred mice) that allow the use of a large number of animals and multiple itera- tions of vaccine products aimed at identifying the best vaccine candidate and early evaluation of immunological end points. However, there are several important considerations that preclude direct extrapolation of the data from small animal studies to humans. Inbred strains of mice that render data more reproducible do not reflect immune response variability in the human outbred populations. Differences in pathogen-recognition receptors may account for differences between humans and rodents in response to microbial vaccines and some adjuvants (Schroder et al. 2012; Lai et al. 2014); dose and regimen of immunization and route of injections are often different between small animal species and humans. There are also species-specific B-cell and T-cell repertoires and HLA presentation of dominant epitopes to CD4 and CD8 T cells. Because of these limitations, some POC studies are conducted in larger animal species in which dose selection and vaccination protocols are expected to be more translatable to humans.

\section{EVALUATION OF VACCINE EFFECTIVENESS IN ANIMAL CHALLENGE MODELS}

There are two main scenarios of vaccine evaluation in animal challenge studies:

1. Using a well-characterized animal challenge model for a final selection of vaccine components and prime-boost protocols to proceed into clinical trials. In specific cases, these studies can be used to support a request for "Fast Track" designation by the FDA for vaccines with an "Unmet Need" designation. The qualifying criteria for Fast Track include a drug/vaccine that is intended to treat a serious condition and nonclinical or clinical data showing the potential to address unmet medical needs (see Guidance for Industry: Expedited Programs for Serious Conditions-Drugs and Biologics at www.fda.gov/downloads/drugs/guidance complianceregulatoryinformation/guid ances/ucm358301.pdf)

2. Using a relevant animal challenge model (i.e., similar pathology to human disease) 
in support of licensure in accordance with the FDA Guidance for Industry: "Product Development under the Animal Rule" (Snoy 2010; Burns 2012) (see www.fda .gov/downloads/drugs/guidancecompliance regulatoryinformation/guidances/ucm399 217.pdf.

Key attributes of relevant animal challenge models for evaluation of vaccine effectiveness:

1. Animal species should show key characteristics of the human disease following exposure to the challenge pathogen (time from exposure to onset of disease, time course/progression of disease, clinical manifestations, morbidity, and lethality).

2. The challenge agent used in the animal study should be relevant to the human disease.

3. The immune marker(s) selected should reflect the protective immune responses generated by humans.

4. The vaccine dose and vaccination schedule chosen for adequate and well-controlled studies in animals should elicit an immune response in animals reflective of that in humans.

5. Ideally, the immunological assays should be species-independent.

6. There should be a robust statistical plan.

In some cases, in the absence of an animal model that directly recapitulates human infection and disease (i.e., human pathogen does not infect or shows different disease patterns in animals), the experimental parameters of the animal challenge study may need to be modified to resemble human disease (i.e., smallpox, papillomavirus [PV], HIV). In other cases, the pathogen needs to be adapted for replication in the animal host. However, host adaptation might lead to changes in pathogen fitness and/or disease course, or to altered antigenic characteristics compared with the unadapted pathogen.

Importantly, even with these limitations, vaccine evaluation in animal challenge studies (not necessarily for approval under the "Animal
Rule") provides an opportunity to conduct indepth immunological measurements and to explore multiple potential surrogate markers of protection or clinical end points. If a primary immunological end point is identified, it may lead to adjustment of the vaccine dose in animal pivotal studies to achieve immune responses at levels comparable to humans ("humanized dose").

\section{SPECIFIC EXAMPLES}

\section{Human Papillomavirus (HPV) Vaccines}

Because of the species-specificity of the papilloma viruses, investigators relied on the biological effects of nonhuman PV in animal models. The bovine virus-like particle ([VLP]/L1) vaccine was protective in cattle against bovine PV infection. Subsequent POC studies in dogs and rabbits with prototype VLP/L1 vaccines showed $\geq 90 \%$ effectiveness in preventing warts following exposure to PV (Breitburd et al. 1995; Suzich et al. 1995; Kirnbauer et al. 1996). These encouraging studies were followed by large clinical vaccine trials in women with HPV VLP/L1, showing high titers of anti-HPV L1 antibodies and protection against type-specific HPV infection and precancerous cervical changes (Harper et al. 2004; Villa et al. 2005). The first HPV vaccine (Gardasil) was approved in the United States in 2006.

\section{Anthrax Vaccines}

Anthrax vaccine adsorbed in combination with a course of antibiotics was approved under the FDA “Animal Rule." Postexposure prophylaxis (PEP) of disease following suspected or confirmed Bacillus anthracis exposure, when administered in conjunction with recommended antibacterial drugs.

In the studies used to support approval of anthrax vaccine, rabbits and nonhuman primates (NHPs) were vaccinated twice (day 0 and 28), and were challenged on day 70 with an aerosolized form of $B$. anthracis spores. Survival was vaccine-dose-dependent and correlated with prechallenge titers of toxin-neutralizing 
H. Golding et al.

antibody (TNA). The prechallenge TNA titers in protected NHPs and rabbits were similar. Statistical analyses confirmed that TNA responses correlated with animal survival after aerosol challenge with $B$. anthracis spores (Burns 2012).

\section{Bridging Animal Protection Data to Humans}

Three assumptions were made:

1. TNA titers in animals could be used to link protection in animals to humans.

2. The distribution of antibody titers obtained in human subjects in an appropriately powered clinical trial, in conjunction with the protective antibody levels in pivotal animal protection studies, could be used to predict that the vaccine is "reasonably likely to provide clinical benefit in humans."

3. The methodology used to measure TNA antibody levels in both the animal studies and humans was species-independent. TNA $\mathrm{NF}_{50} \geq 0.56$ (on day 69-70) corresponded with $70 \%$ probability of survival in both animal species. Importantly, the protective TNA titers in animals could be bridged to TNA titers in humans at day 63 , that is, a time point shortly after the recommended 60-day antibiotic regimen is discontinued and the risk of infection resulting from germination of residual spores is increased. Ultimately, the lower bound of the 95\% CI of the proportion achieving TNA $\mathrm{NF}_{50} \geq 0.56$ at day 63 was used for approval of BioThrax under the "Animal Rule" (Ionin et al. 2013).

\section{EBOLA VACCINES}

Ebola virus (EBOV) and Marburg virus (MARV), members of the Filoviridae family, cause an acute and rapidly progressing hemorrhagic fever (HF) with mortality rates up to 90\% (Miranda et al. 1999; Peters and Khan 1999; Roels et al. 1999; Sadek et al. 1999). Several animal species including guinea pigs and NHPs were evaluated for pathogenesis, therapeutic, and vaccine studies (Hevey et al. 1998; Schou and Hansen 2000; Geisbert et al. 2002).
The unprecedented large outbreak of EBOV in 2014-2015 in West Africa showed the urgent need for an EBOV vaccine. Several vaccine candidates moved rapidly from preclinical studies in NHPs into phase $1 / 2$ clinical studies in the United States and several countries in West Africa. However, because most phase 3 clinical trials took place toward the tail end of the EBOV outbreak, they are unlikely to fulfill the criteria of traditional pathways to licensure, based on randomized controlled trials (RCTs) with clinical end points (Chowell and Viboud 2015; Chowell et al. 2015; Cleaton et al. 2016).

Currently, the two most likely options for approval of EBOV vaccines are (Krause et al. 2015a,b):

1. Accelerated approval based on a surrogate immunological end point that is "reasonably likely" to predict clinical benefit. The immunological end point could be defined based on animal studies, and/or from naturally infected or exposed/protected humans.

\section{Licensure based on the "Animal Rule."}

Both types of vaccine approval will require postlicensure studies (probably during future EBOV outbreaks) to show clinical benefit in humans.

\section{MAIN CHALLENGES TO ESTABLISHMENT OF VALIDATED ANIMAL MODEL FOR EBOV VACCINES}

\section{Pathogen (Virus Strain, Dose, Route-of- Exposure)}

NHPs including rhesus macaques and cynomolgus macaques infected with EBOV and MARV show similar pathology and lethality rates as observed in humans and therefore have been used extensively (Geisbert et al. 2003a,b). However, the susceptibility to infection, disease manifestation, and infection outcome differ between NHP species depending on the virus strain, route of administration, and challenge dose. An additional complication to studying EBOV vaccines in NHPs is that the natural exposure in humans may differ from the route of infection used in animal studies: intramuscular 
infection with $10^{3}$ pfu (plaque-forming units) (Marzi et al. 2015a,b,c) or aerosol administration in the case of studies of bioterrorism agents (Geisbert et al. 2008; Twenhafel et al. 2013).

\section{Surrogate Markers in Animal Studies and} Assays

The predominant immune response and surrogate markers may vary among vaccine platforms. The replicating vesicular stomatitis virus (VSV)-EBOV-Zaire glycoprotein (GP) vaccine is likely to protect by antibody-dependent mechanisms: protection of cynomolgus macaques vaccinated with VSV-EBOV-Zaire $(2 \times$ $10^{7} \mathrm{pfu}$ ) from lethal challenge with an EBOVMakona strain $\left(10^{3} \mathrm{pfu}\right)$ correlated with high titers of anti-EBOV-GP IgGs in surviving versus nonsurviving animals (1:12,805 and 1:64, respectively) (Wong et al. 2012). However, in other studies that used the same vaccine platform, titers of anti-GP antibodies that correlated with protection varied significantly (between $10^{2}$ and $\geq 10^{4}$ ), possibly reflecting differences in the ELISA-binding assays (Marzi et al. 2015c). Measurements of neutralizing antibodies are more likely to be species-independent, but so far they showed high variability among laboratories. There is also a clear need to replace BSL-4restricted assays using live wild-type EBOV with reporter-gene-based neutralization assays that can be conducted in BSL-2 facilities. However, these assays did not correlate with protection any better than the EBOV-specific ELISA in NHPs.

In contrast with replicating VSV-EBOV vaccine, protection of NHPs against EBOV challenge after vaccination with nonreplicating adenovirus-based vaccines appears to be mediated primarily by $\mathrm{CD}^{+}$T cells (Geisbert et al. 2011; Sullivan et al. 2011; Stanley et al. 2014). Cellmediated immunity (CMI) assays are particularly difficult to validate, and data from CMI assays in animals is difficult to bridge to humans because of differences in MHC-HLA restrictions.

\section{Bridging Animal Protection Data to Humans}

Interim reports on safety and immunogenicity from several ongoing clinical trials of EBOV vaccine have been recently published, including IgG ELISA data. ChAd3-EBOV-Zaire vaccine administered at a dose range of $1 \times 10^{10}-1 \times$ $10^{11}$ particles induced good IgG titers mainly in the highest dose group $(\geq 1000$ and $\geq 1500$ in $90 \%$ and $60 \%$ of subjects, respectively) (Tapia et al. 2016). In the case of VSV-EBOV-Zaire vaccine, the IgG GMTs were 4079 and 1300 for the groups receiving $20 \times 10^{6}$ and $3 \times 10^{6} \mathrm{pfu}$, respectively (Regules et al. 2015).

In addition, one report of vaccine effectiveness $(\geq 80 \%)$ was published from a study that used ring vaccination with the VSV-ZEBOV (one dose of $20 \times 10^{6} \mathrm{pfu}$ ) during the Ebola outbreak in Guinea (Henao-Restrepo et al. 2015). Unfortunately, only limited numbers of blood samples were collected, and no correlates of protection were reported.

There are several important observations regarding available EBOV IgG data that may complicate bridging NHP data to humans:

1. IgG titers reported from human vaccine trials were significantly lower (up to 10-fold) compared with IgG titers measured in most NHP studies (Ewer et al. 2016).

2. ELISA assays used in NHP and human studies do not use identical sets of reagents.

3. Data on passive immunity: cocktails of MAbs (including ZMapp)-protected NHPs, both pre- and postinfection prophylaxis (Murin et al. 2014), but did not reach statistical significance in a randomized controlled trial in Ebola-confirmed subjects (The PREVAIL II Writing Group 2016). Postexposure treatment of NHPs with polyclonal EBOV (or MARV)-specific IgGs provided protection from lethality at various levels (Dye et al. 2012). In contrast, transfusion of up to $500 \mathrm{ml}$ of convalescent plasma in 84 patients with confirmed EBOV infection did not result in significant improvement in survival (van Griensven et al. 2016a,b).

In summary, several parameters need to be improved to make NHP models predictive of effectiveness of EBOV vaccines and for licensure under the "Animal Rule." These include further validation of the animal challenge models, 
H. Golding et al.

development of species-independent validated immunological assays, and identification of antibody titers (and/or CMI levels) reasonably likely to predict clinical benefit in humans.

\section{HIV-1 VACCINES}

Evaluation of HIV vaccine effectiveness in animal challenge models is difficult because of the fact that the virus infects only humans (with the exception of chimpanzees, which are protected from challenge studies under a moratorium). NHPs of different species infected with simian immunodeficiency viruses (SIVs) or with recombinant SIVs containing envelopes from HIV strains (SHIVs) have been used in the past as a surrogate of HIV infections. In these studies, NHPs were infected via systemic (intravenous) or mucosal (intravaginal, intrarectal) routes with either a single high-dose challenge or by repeat administration of small doses (for mucosal challenge). The level of virus replication and disease outcome varied significantly (Sharma et al. 2015; Del Prete et al. 2016; Lopker et al. 2016).

The data from early protection studies in NHPs were not predictive of vaccine efficacy trials in humans. Rhesus macaques immunized with adenovirus serotype 5 (Ad5) vectored SIV gag protein alone or as a booster inoculation after priming with DNA showed strong antigag immune response, reduction of peak viremia, and control of viremia after intravenous challenge with pathogenic SHIV 89.6P virus (Shiver 2002). In other studies, Indian rhesus macaques immunized with an Ad5-based vaccine expressing SIV gag, tat, rev, and nef proteins as a booster to DNA prime showed significant reduction in viremia after intrarectal challenge with SIVmac239 (Wilson 2006). Yet, clinical trials that used Ad5-based vaccines failed to show efficacy. Most revealing was the failure of the Merck phase 3 vaccine trial of Ad5-based vaccine expressing several internal HIV genes (MRKAd5) (STEP) in 3000 volunteers, which resulted in early termination and evidence of increased number of infections in the vaccine arm compared with the placebo arm (Buchbinder et al. 2008; McElrath et al. 2008).
A subsequent phase 2B trial (HVTN 505) of a DNA-prime followed by rAd5 vaccine regimen (containing both Gag-Pol and Env genes from three clades) in a high-risk population was also halted for futility with no vaccine efficacy (but no enhanced infection rate) (Hammer et al. 2013). There are a number of possible reasons why an Ad5 vectored vaccine that conferred protection in NHPs failed to show efficacy in humans: NHPs developed higher levels of cellmediated immune response following Ad5/ HIV and DNA/Ad5/HIV vaccination compared with humans (Bett et al. 2010); many people have been exposed to Ad5 and therefore have immunity to this viral vector; and mismatch between the vaccine used in NHPs and infecting HIV strains in vaccine recipients.

In a subsequent National Institute of Allergy and Infectious Diseases (NIAID) mini-summit, evidence was presented that the Ad5/HIV vaccine increased the frequency of Ad5-specific $\mathrm{CD}^{+} \mathrm{T}$ cells in the gastrointestinal mucosa of NHPs after rAd5-SIV vaccination, and increased SIV acquisition (Bukh et al. 2014). Furthermore, human gut biopsies of individuals vaccinated with DNA prime and rAd5/HIV boost (in HVTN 204 and HVTN 505) revealed a high number of activated adenovirus-specific $\mathrm{CD}^{+}{ }^{+} \mathrm{CCR}^{+}{ }^{+} \mathrm{T}$ cells (but not HIV-specific T cells) (Fauci et al. 2014). It was concluded that any vaccine strategy that activates $\mathrm{CD} 4{ }^{+} \mathrm{T}$ cells at the mucosal site could increase risk of HIV infection (Fauci et al. 2014).

Thus far, only one HIV vaccine trial (RV144) that used a pox vector (ALVAC/HIV) prime followed by gp120 bivalent envelope (B/ E) proteins boost achieved a modest $31 \%$ efficacy in a cohort of low-risk individuals $(16,000)$ in Thailand (Rerks-Ngarm et al. 2009). Extensive posttrial studies identified a set of immunological end points that either positively (antiV1-V2 antibodies, IgG3 subclass) or negatively (IgA antibodies) correlated with protection. No strong HIV-neutralizing antibodies or cellmediated immunity were detected in uninfected vaccine recipients (Haynes et al. 2012; Yates et al. 2014; Zolla-Pazner et al. 2014). No preclinical studies predicted the outcome of RV144. However, recently, an NHP study using 
an SIV vaccine prototype (ALVAC-SIV+SIV gp120/alum or MF59) showed delayed acquisition of $\operatorname{SIV}_{\text {mac }} 251$ via the rectal route. No clearcut correlate of protection was identified. However, delayed virus acquisition correlated to some degree with increased numbers of mucosal innate lymphoid cells (ILCs) that produce interleukin (IL)-17 as well as with mucosal IgG to cyclic V2. Transcriptome analysis revealed increase in RAS pathway genes that are likely to up-regulate ILC activity and natural killer (NK) cell target genes (Vaccari et al. 2016). It will be very difficult to confirm these findings in an HIV vaccine trial.

The field of HIV vaccines has recently shifted toward vaccine designs that include "native" forms of envelope trimers and sequential envelope immunogens predicted to bind the unmutated germline $\mathrm{B}$-cell receptor (BCR) in naïve $\mathrm{B}$ cells and drive somatic mutations and selections of broadly neutralizing antibodies against conserved targets in the HIV spike. It is hoped that the new immunogens will provide broad coverage against diverse circulating strains, likely to be transmitted through the mucosal routes (Xiao et al. 2009a,b; Fera et al. 2014; Mann and Ndung'u 2015; Mascola 2015). Therefore, the ability of NHP challenge studies to predict HIV vaccine efficacy will need to be reevaluated.

\section{VACCINE DESIGN AND MEASUREMENT OF IMMUNE RESPONSES IN NHPs: CONFOUNDING FACTORS}

The vaccine candidate to be tested in NHPs should be very similar to the intended human vaccine. The use of an SIV version of the human vaccine is highly questionable, especially for envelope-based vaccines, because the gp120 envelope is significantly different between SIV and HIV. Furthermore, the putative immunoglobulin germline predecessors of highly mutated broadly neutralizing antibodies, found in some HIV patients, are different between rhesus macaques and humans (Yuan et al. 2011).

What antibody functions are most relevant for in vivo protection if no neutralization of tier 2 viruses can be shown? Antibody-dependent cell-mediated cytotoxicity (ADCC) and anti- body-dependent cellular phagocytosis (ADCP) have been implicated in RV144. Both depend on engagement of host effector cells expressing FcRs and possibly activation of the complement system. These mechanisms may vary between NHPs and humans because of diversified FcRs and their cell-specific distribution/expression (Chan et al. 2016). They are also affected by glycosylation patterns and antibody isotypes (Chung et al. 2014, 2015; Santra et al. 2015; Tay et al. 2016). Furthermore, passively transferred polyclonal antibodies enriched for ADCC activity (from an elite controller) failed to protect macaques from mucosal challenge (Dugast et al. 2014). This and other studies illustrate the difficulties in bridging in vitro assays with in vivo protective activity (Sholukh et al. 2014; Hessell and Haigwood 2015).

CMI against internal genes are likely to be determined by species-specific antigen processing/presentation in the context of diverse HLA proteins. The internal gene sequences are not identical between SIV and HIV. NHP CMI may not predict human responses. To date, most humoral and CMI assays have not been standardized and were not shown to be species-independent. So, bridging NHP data to humans could be a major obstacle.

\section{WHICH NHP CHALLENGE VIRUSES ARE SUITABLE FOR PREDICTING HIV VACCINE EFFECTIVENESS?}

\section{SIV Challenge Models}

Indian-origin rhesus macaques are most often used for AIDS research, showing high viral loads and disease progression similar to HIV infections in humans. Although these SIV infection models could be of value in POC studies for limited vaccine prototypes, they are unlikely to be predictive of HIV vaccine effectiveness in humans, especially for the next-generation vaccines as discussed above.

\section{SHIV Challenge Models}

Most of the early constructed SHIVs contained envelopes derived from chronically infected pa- 
H. Golding et al.

tients representing a limited number of clades, and did not include envelopes of transmitted viruses. Furthermore, they required multiple animal-to-animal passages in rhesus macaques to reach high-level replication and disease patterns similar to human HIV. This adaptation often resulted in changes to the envelope configurations (more open trimers), altered antigenic profile and susceptibility to neutralization by MAbs, and sCD4 (Boyd et al. 2015; Sharma et al. 2015).

More recently derived SHIVs are better adapted to mucosal infection of NHPs without multiple passages in vivo. Importantly, they represent transmitted/founder $(\mathrm{T} / \mathrm{F})$ strains from diverse clades (A, B, C, D, CRF01_AE). Some new SHIVs contain specific mutations designed to improve interaction with the rhesus macaque CD4 receptor (Del Prete et al. 2014; Asmal et al. 2015; Li et al. 2016). Large stocks will need to be prepared from the new SHIVs and subjected to careful titration and evaluation of genetic homogeneity and replication rates in vivo after in vitro expansion.

Protection against repeat low-dose mucosal challenge will depend on the size of the challenge dose and the number of repeat inoculations. The most significant hurdle in predicting vaccine effectiveness against HIV is the need to protect against heterologous viral swarms that undergo continuous evolution in HIV patients. Therefore, protection against more than one SHIV challenge in NHPs (mismatched clade/ strain compared with vaccine envelope) may be required to predict vaccine effectiveness in humans.

Finally, evidence of protection in NHPs should be correlated with in vitro standardized assays, easily transferrable to human trials. Bridging data from challenge studies in NHPs to humans will rely on identifying the most reliable immunological end point and its postvaccination levels predictive of protection from infection/disease in vivo (as was established for the anthrax vaccine). Currently, it is not expected that HIV vaccines will be approved based on the "Animal Rule."

\section{CONCLUDING REMARKS}

The establishment of animal models predictive of vaccine effectiveness in humans has been fraught with difficulties with low success rate to date. Table 1 summarizes the current status of the animal models for the four pathogens discussed above. Each pathogen presents

Table 1. Summary of animal models for predicting vaccine effectiveness

\begin{tabular}{|c|c|c|c|c|c|c|}
\hline \multirow[b]{2}{*}{ Pathogen } & \multicolumn{2}{|c|}{$\begin{array}{c}\text { Key characteristics of animal } \\
\text { challenge model }\end{array}$} & \multicolumn{2}{|c|}{$\begin{array}{l}\text { Immunological end points/ } \\
\text { assays }\end{array}$} & \multirow[b]{2}{*}{$\begin{array}{l}\text { Bridging } \\
\text { animal data } \\
\text { to human }\end{array}$} & \multirow[b]{2}{*}{$\begin{array}{c}\text { Animal studies } \\
\text { predictive of } \\
\text { vaccine } \\
\text { protection against } \\
\text { disease in humans }\end{array}$} \\
\hline & $\begin{array}{c}\text { Pathogen } \\
\text { challenge stock } \\
\text { (human; animal } \\
\text { prototype) }\end{array}$ & $\begin{array}{l}\text { Disease } \\
\text { pattern } \\
\text { similar to } \\
\text { humans }\end{array}$ & $\begin{array}{l}\text { Correlate of } \\
\text { protection } \\
\text { identified }\end{array}$ & $\begin{array}{c}\text { Species- } \\
\text { independent } \\
\text { assay available }\end{array}$ & & \\
\hline $\mathrm{HPV}$ & $\begin{array}{l}\text { Animal pathogen } \\
\text { prototypes } \\
\text { (bovine, dog) }\end{array}$ & Partially & Yes & No & Yes & Yes \\
\hline Anthrax $^{\mathrm{a}}$ & $\begin{array}{l}\text { Human pathogen/ } \\
\text { validated }\end{array}$ & Yes & Yes & Yes/validated & Yes & Yes \\
\hline Ebola & Human pathogen & Yes & Partially & $\begin{array}{l}\text { Not finalized; } \\
\text { not validated }\end{array}$ & No & Partially \\
\hline HIV & $\begin{array}{l}\text { Animal pathogen } \\
\text { prototypes (SIV, } \\
\text { SHIV) }\end{array}$ & Partially & No & No & No & No \\
\hline
\end{tabular}

HPV, Human papillomavirus; SIV, simian immunodeficiency virus; SHIV, HIV strain.

aAnthrax vaccine was approved under the FDA "Animal Rule." 
unique hurdles related to the robustness of the animal challenge model, availability of wellcharacterized challenge stocks, and selection of optimal dose, route, and schedule of infection. The comparability of the immune responses to vaccine immunogens in animals versus humans and establishment of "speciesindependent" surrogate of protection beneficial for bridging data from the animal challenge studies to human clinical trials. This is a more stringent requirement for vaccines that are likely to be approved under the "Animal Rule." For traditional approval, the correlate/surrogate of protection could be identified/confirmed subsequent to a successful phase 3 vaccine trial.

\section{ACKNOWLEDGMENTS}

We appreciate the input of Dr. Drusilla Burns, Center for Biologics Evaluation and Research, Food and Drug Administration (CBER, FDA). We thank Drs. Steve Rubin and Carol Weiss for a thorough review of the article.

\section{REFERENCES}

Asmal M, Luedemann C, Lavine CL, Mach LV, Balachandran H, Brinkley C, Denny TN, Lewis MG, Anderson H, Pal R, et al. 2015. Infection of monkeys by simian-human immunodeficiency viruses with transmitted/founder clade C HIV-1 envelopes. Virology 475: 37-45.

Bett AJ, Dubey SA, Mehrotra DV, Guan L, Long R, Anderson K, Collins K, Gaunt C, Fernandez R, Cole S, et al. 2010. Comparison of $\mathrm{T}$ cell immune responses induced by vectored HIV vaccines in non-human primates and humans. Vaccine 28: 7881-7889.

Boyd DF, Peterson D, Haggarty BS, Jordan AP, Hogan MJ, Goo L, Hoxie JA, Overbaugh J. 2015. Mutations in HIVenvelope that enhance entry with the macaque CD4 receptor alter antibody recognition by disrupting quaternary interactions within the trimer. J Virol 89: 894-907.

Breitburd F, Kirnbauer R, Hubbert NL, Nonnenmacher B, Trin-Dinh-Desmarquet C, Orth G, Schiller JT, Lowy DR. 1995. Immunization with viruslike particles from cottontail rabbit papillomavirus (CRPV) can protect against experimental CRPV infection. J Virol 69: 3959-3963.

Buchbinder SP, Mehrotra DV, Duerr A, Fitzgerald DW, Mogg R, Li D, Gilbert PB, Lama JR, Marmor M, Del Rio C, et al. 2008. Efficacy assessment of a cell-mediated immunity HIV-1 vaccine (the Step study): A doubleblind, randomised, placebo-controlled, test-of-concept trial. Lancet 372: 1881-1893.

Bukh I, Calcedo R, Roy S, Carnathan DG, Grant R, Qin Q, Boyd S, Ratcliffe SJ, Veeder CL, Bellamy SL, et al. 2014 Increased mucosal $\mathrm{CD}^{+}{ }^{+} \mathrm{T}$ cell activation in rhesus macaques following vaccination with an adenoviral vector. J Virol 88: 8468-8478.

Burns DL. 2012. Licensure of vaccines using the Animal Rule. Curr Opin Virol 2: 353-356.

Chan YN, Boesch AW, Osei-Owusu NY, Emileh A, Crowley AR, Cocklin SL, Finstad SL, Linde CH, Howell RA, Zentner I, et al. 2016. IgG binding characteristics of rhesus macaque FcyR. J Immunol 197: 2936-2947.

Chowell G, Viboud C. 2015. Ebola vaccine trials: A race against the clock. Lancet Infect Dis 15: 624-626.

Chowell G, Viboud C, Hyman JM, Simonsen L. 2015. The Western Africa Ebola virus disease epidemic exhibits both global exponential and local polynomial growth rates. PLoS Curr Jan 21, Edition 1.

Chung AW, Ghebremichael M, Robinson H, Brown E, Choi I, Lane S, Dugast AS, Schoen MK, Rolland M, Suscovich TJ, et al. 2014. Polyfunctional Fc-effector profiles mediated by IgG subclass selection distinguish RV144 and VAX003 vaccines. Sci Transl Med 6: $228 \mathrm{ra} 238$.

Chung AW, Kumar MP, Arnold KB, Yu WH, Schoen MK, Dunphy LJ, Suscovich TJ, Frahm N, Linde C, Mahan AE, et al. 2015. Dissecting polyclonal vaccine-induced humoral immunity against HIV using systems serology. Cell 163: 988-998.

Cleaton JM, Viboud C, Simonsen L, Hurtado AM, Chowell G. 2016. Characterizing Ebola transmission patterns based on Internet news reports. Clin Infect Dis 62: 2431.

Del Prete GQ, Ailers B, Moldt B, Keele BF, Estes JD, Rodriguez A, Sampias M, Oswald K, Fast R, Trubey CM, et al. 2014. Selection of unadapted, pathogenic SHIVs encoding newly transmitted HIV-1 envelope proteins. Cell Host Microbe 16: 412-418.

Del Prete GQ, Lifson JD, Keele BF. 2016. Nonhuman primate models for the evaluation of HIV-1 preventive vaccine strategies: Model parameter considerations and consequences. Curr Opin HIVAIDS 11: 546-554.

Dugast AS, Chan Y, Hoffner M, Licht A, Nkolola J, Li H, Streeck H, Suscovich TJ, Ghebremichael M, Ackerman $\mathrm{ME}$, et al. 2014. Lack of protection following passive transfer of polyclonal highly functional low-dose nonneutralizing antibodies. PLoS ONE 9: e97229.

Dye JM, Herbert AS, Kuehne AI, Barth JF, Muhammad MA, Zak SE, Ortiz RA, Prugar LI, Pratt WD. 2012. Postexposure antibody prophylaxis protects nonhuman primates from filovirus disease. Proc Natl Acad Sci 109: 5034-5039.

Ewer K, Rampling T, Venkatraman N, Bowyer G, Wright D, Lambe T, Imoukhuede EB, Payne R, Fehling SK, Strecker T, et al. 2016. A monovalent chimpanzee adenovirus Ebola vaccine boosted with MVA. N Engl J Med 374: 1635-1646.

Fauci AS, Marovich MA, Dieffenbach CW, Hunter E, Buchbinder SP. 2014. Immunology. Immune activation with HIV vaccines. Science 344: 49-51.

Fera D, Schmidt AG, Haynes BF, Gao F, Liao HX, Kepler TB, Harrison SC. 2014. Affinity maturation in an HIV broadly neutralizing B-cell lineage through reorientation of variable domains. Proc Natl Acad Sci 111: 10275-10280. 
H. Golding et al.

Geisbert TW, Pushko P, Anderson K, Smith J, Davis KJ, Jahrling PB. 2002. Evaluation in nonhuman primates of vaccines against Ebola virus. Emerg Infect Dis 8: 503-507.

Geisbert TW, Hensley LE, Larsen T, Young HA, Reed DS, Geisbert JB, Scott DP, Kagan E, Jahrling PB, Davis KJ. 2003a. Pathogenesis of Ebola hemorrhagic fever in cynomolgus macaques: Evidence that dendritic cells are early and sustained targets of infection. Am J Pathol 163: 2347-2370.

Geisbert TW, Young HA, Jahrling PB, Davis KJ, Larsen T, Kagan E, Hensley LE. 2003b. Pathogenesis of Ebola hemorrhagic fever in primate models: Evidence that hemorrhage is not a direct effect of virus-induced cytolysis of endothelial cells. Am J Pathol 163: 23712382.

Geisbert TW, Daddario-Dicaprio KM, Geisbert JB, Reed DS, Feldmann F, Grolla A, Stroher U, Fritz EA, Hensley LE, Jones SM, et al. 2008. Vesicular stomatitis virus-based vaccines protect nonhuman primates against aerosol challenge with Ebola and Marburg viruses. Vaccine 26: 6894-6900.

Geisbert TW, Bailey M, Hensley L, Asiedu C, Geisbert J, Stanley D, Honko A, Johnson J, Mulangu S, Pau MG, et al. 2011. Recombinant adenovirus serotype 26 (Ad26) and Ad35 vaccine vectors bypass immunity to Ad5 and protect nonhuman primates against Ebolavirus challenge. J Virol 85: 4222-4233.

Hammer SM, Sobieszczyk ME, Janes H, Karuna ST, Mulligan MJ, Grove D, Koblin BA, Buchbinder SP, Keefer MC, Tomaras GD, et al. 2013. Efficacy trial of a DNA/ rAd5 HIV-1 preventive vaccine. $N$ Engl J Med 369: 2083-2092.

Harper DM, Franco EL, Wheeler C, Ferris DG, Jenkins D, Schuind A, Zahaf T, Innis B, Naud P, De Carvalho NS, et al. 2004. Efficacy of a bivalent L1 virus-like particle vaccine in prevention of infection with human papillomavirus types 16 and 18 in young women: A randomised controlled trial. Lancet 364: 1757-1765.

Haynes BF, Gilbert PB, McElrath MJ, Zolla-Pazner S, Tomaras GD, Alam SM, Evans DT, Montefiori DC, Karnasuta C, Sutthent R, et al. 2012. Immune-correlates analysis of an HIV-1 vaccine efficacy trial. $N$ Engl J Med 366: 1275 1286.

Henao-Restrepo AM, Longini IM, Egger M, Dean NE, Edmunds WJ, Camacho A, Carroll MW, Doumbia M, Draguez B, Duraffour S, et al. 2015. Efficacy and effectiveness of an rVSV-vectored vaccine expressing Ebola surface glycoprotein: Interim results from the Guinea ring vaccination cluster-randomised trial. Lancet 386: 857-866.

Hessell AJ, Haigwood NL. 2015. Animal models in HIV-1 protection and therapy. Curr Opin HIVAIDS 10: 170-176.

Hevey M, Negley D, Pushko P, Smith J, Schmaljohn A. 1998. Marburg virus vaccines based upon alphavirus replicons protect guinea pigs and nonhuman primates. Virology 251: $28-37$.

Ionin B, Hopkins RJ, Pleune B, Sivko GS, Reid FM, Clement KH, Rudge TLJr, Stark GV, Innes A, Sari S, et al. 2013. Evaluation of immunogenicity and efficacy of anthrax vaccine adsorbed for postexposure prophylaxis. Clin Vaccine Immunol 20: 1016-1026.
Kirnbauer R, Chandrachud LM, O'Neil BW, Wagner ER, Grindlay GJ, Armstrong A, McGarvie GM, Schiller JT, Lowy DR, Campo MS. 1996. Virus-like particles of bovine papillomavirus type 4 in prophylactic and therapeutic immunization. Virology 219: 37-44.

Krause PR, Bryant PR, Clark T, Dempsey W, Henchal E, Michael NL, Regules JA, Gruber MF. 2015a. Immunology of protection from Ebola virus infection. Sci Transl Med 7: 286ps211.

Krause PR, Cavaleri M, Coleman G, Gruber MF. 2015b. Approaches to demonstration of Ebola virus vaccine efficacy. Lancet Infect Dis 15: 627-629.

Lai CY, Liu YL, Yu GY, Maa MC, Leu TH, Xu C, Luo Y, Xiang R, Chuang TH. 2014. TLR7/8 agonists activate a mild immune response in rabbits through TLR8 but not TLR7. Vaccine 32: 5593-5599.

Li H, Wang S, Kong R, Ding W, Lee FH, Parker Z, Kim E, Learn GH, Hahn P, Policicchio B, et al. 2016. Envelope residue 375 substitutions in simian-human immunodeficiency viruses enhance CD4 binding and replication in rhesus macaques. Proc Natl Acad Sci 113: E3413-E3422.

Lopker MJ, Del Prete GQ, Estes JD, Li H, Reid C, Newman L, Lipkey L, Camus C, Easlick JL, Wang S, et al. 2016. Derivation and characterization of pathogenic transmitted/ founder molecular clones from simian immunodeficiency virus SIVsmE660 and SIVmac251 following mucosal infection. J Virol 90: 8435-8453.

Mann JK, Ndung'u T. 2015. HIV-1 vaccine immunogen design strategies. Virol J 12: 3.

Marzi A, Feldmann F, Geisbert TW, Feldmann H, Safronetz D. 2015a. Vesicular stomatitis virus-based vaccines against Lassa and Ebola viruses. Emerg Infect Dis 21: 305-307.

Marzi A, Feldmann F, Hanley PW, Scott DP, Gunther S, Feldmann H. 2015b. Delayed disease progression in cynomolgus macaques infected with Ebola virus Makona strain. Emerg Infect Dis 21: 1777-1783.

Marzi A, Robertson SJ, Haddock E, Feldmann F, Hanley PW, Scott DP, Strong JE, Kobinger G, Best SM, Feldmann H. 2015c. VSV-EBOV rapidly protects macaques against infection with the 2014/15 Ebola virus outbreak strain. Science 349: 739-742.

Mascola JR. 2015. HIV. The modern era of HIV-1 vaccine development. Science 349: 139-140.

McElrath MJ, De Rosa SC, Moodie Z, Dubey S, Kierstead L, Janes H, Defawe OD, Carter DK, Hural J, Akondy R, et al. 2008. HIV-1 vaccine-induced immunity in the test-ofconcept Step Study: A case-cohort analysis. Lancet 372: 1894-1905.

Miranda ME, Ksiazek TG, Retuya TJ, Khan AS, Sanchez A, Fulhorst CF, Rollin PE, Calaor AB, Manalo DL, Roces MC, et al. 1999. Epidemiology of Ebola (subtype Reston) virus in the Philippines, 1996. J Infect Dis 179: S115S119.

Murin CD, Fusco ML, Bornholdt ZA, Qiu X, Olinger GG, Zeitlin L, Kobinger GP, Ward AB, Saphire EO. 2014. Structures of protective antibodies reveal sites of vulnerability on Ebola virus. Proc Natl Acad Sci 111: 17182-17187.

Peters CJ, Khan AS. 1999. Filovirus diseases. Curr Top Microbiol Immunol 235: 85-95.

Regules JA, Beigel JH, Paolino KM, Voell J, Castellano AR, Munoz P, Moon JE, Ruck RC, Bennett JW, Twomey PS, 
et al. 2015. A recombinant vesicular stomatitis virus Ebola vaccine-Preliminary report. $N$ Engl J Med.

Rerks-Ngarm S, Pitisuttithum P, Nitayaphan S, Kaewkungwal J, Chiu J, Paris R, Premsri N, Namwat C, de Souza M, Adams E, et al. 2009. Vaccination with ALVAC and AIDSVAX to prevent HIV-1 infection in Thailand. $N$ Engl J Med 361: 2209-2220.

Roels TH, Bloom AS, Buffington J, Muhungu GL, Mac Kenzie WR, Khan AS, Ndambi R, Noah DL, Rolka HR, Peters CJ, et al. 1999. Ebola hemorrhagic fever, Kikwit, Democratic Republic of the Congo, 1995: Risk factors for patients without a reported exposure. J Infect Dis 179: $S 92-97$.

Sadek RF, Khan AS, Stevens G, Peters CJ, Ksiazek TG. 1999. Ebola hemorrhagic fever, Democratic Republic of the Congo, 1995: Determinants of survival. J Infect Dis 179: S24-27.

Santra S, Tomaras GD, Warrier R, Nicely NI, Liao HX, Pollara J, Liu P, Alam SM, Zhang R, Cocklin SL, et al. 2015. Human non-neutralizing HIV-1 envelope monoclonal antibodies limit the number of founder viruses during SHIV mucosal infection in rhesus macaques. PLoS Pathog 11: e1005042.

Schou S, Hansen AK. 2000. Marburg and Ebola virus infections in laboratory non-human primates: A literature review. Comp Med 50: 108-123.

Schroder K, Irvine KM, Taylor MS, Bokil NJ, Le Cao KA, Masterman KA, Labzin LI, Semple CA, Kapetanovic R, Fairbairn L, et al. 2012. Conservation and divergence in Toll-like receptor 4-regulated gene expression in primary human versus mouse macrophages. Proc Natl Acad Sci 109: E944-E953.

Sharma A, Boyd DF, Overbaugh J. 2015. Development of SHIVs with circulating, transmitted HIV-1 variants. J Med Primatol 44: 296-300.

Shiver JW. 2002. Replication-incompetent adenoviral vaccine vector elicits effective anti-immunodeficiency virus immunity. Nature 415: 331-335.

Sholukh AM, Byrareddy SN, Shanmuganathan V, Hemashettar G, Lakhashe SK, Rasmussen RA, Watkins JD, Vyas HK, Thorat S, Brandstoetter T, et al. 2014. Passive immunization of macaques with polyclonal anti-SHIV IgG against a heterologous tier 2 SHIV: Outcome depends on IgG dose. Retrovirology 11: 8 .

Snoy PJ. 2010. Establishing efficacy of human products using animals: The US food and drug administration's "animal rule." Vet Pathol 47: 774-778.

Stanley DA, Honko AN, Asiedu C, Trefry JC, Lau-Kilby AW, Johnson JC, Hensley L, Ammendola V, Abbate A, Grazioli F, et al. 2014. Chimpanzee adenovirus vaccine generates acute and durable protective immunity against ebolavirus challenge. Nat Med 20: 1126-1129.

Sullivan NJ, Hensley L, Asiedu C, Geisbert TW, Stanley D, Johnson J, Honko A, Olinger G, Bailey M, Geisbert JB, et al. 2011. CD8 ${ }^{+}$cellular immunity mediates rAd5 vaccine protection against Ebola virus infection of nonhuman primates. Nat Med 17: 1128-1131.

Suzich JA, Ghim SJ, Palmer-Hill FJ, White WI, Tamura JK, Bell JA, Newsome JA, Jenson AB, Schlegel R. 1995 Systemic immunization with papillomavirus L1 protein completely prevents the development of viral mucosal papillomas. Proc Natl Acad Sci 92: 11553-11557.
Tapia MD, Sow SO, Lyke KE, Haidara FC, Diallo F, Doumbia M, Traore A, Coulibaly F, Kodio M, Onwuchekwa U, et al. 2016. Use of ChAd3-EBO-Z Ebola virus vaccine in Malian and US adults, and boosting of Malian adults with MVA-BN-Filo: A phase 1, single-blind, randomised trial, a phase $1 \mathrm{~b}$, open-label and doubleblind, dose-escalation trial, and a nested, randomised, double-blind, placebo-controlled trial. Lancet Infect Dis 16: $31-42$.

Tay MZ, Liu P, Williams LD, McRaven MD, Sawant S, Gurley TC, Xu TT, Dennison SM, Liao HX, Chenine AL, et al. 2016. Antibody-mediated internalization of infectious HIV-1 virions differs among antibody isotypes and subclasses. PLoS Pathog 12: e1005817.

The PREVAIL II Writing Group, for the Multi-National PREVAIL II Study Team. 2016. A randomized, controlled trial of ZMapp for Ebola virus infection. N Engl J Med 375: $1448-1456$

Twenhafel NA, Mattix ME, Johnson JC, Robinson CG, Pratt WD, Cashman KA, Wahl-Jensen V, Terry C, Olinger GG, Hensley LE, et al. 2013. Pathology of experimental aerosol Zaire ebolavirus infection in rhesus macaques. Vet Pathol 50: 514-529.

Vaccari M, Gordon SN, Fourati S, Schifanella L, Liyanage NP, Cameron M, Keele BF, Shen X, Tomaras GD, Billings E, et al. 2016. Adjuvant-dependent innate and adaptive immune signatures of risk of SIVmac251 acquisition. Nat Med 22: 762-770.

van Griensven J, De Weiggheleire A, Delamou A, Smith PG, Edwards T, Vandekerckhove P, Bah EI, Colebunders R, Herve I, Lazaygues C, et al. 2016a. The use of Ebola convalescent plasma to treat Ebola virus disease in resourceconstrained settings: A perspective from the field. Clin Infect Dis 62: 69-74.

van Griensven J, Edwards T, de Lamballerie X, Semple MG, Gallian P, Baize S, Horby PW, Raoul H, Magassouba N, Antierens A, et al. 2016b. Evaluation of convalescent plasma for Ebola virus disease in Guinea. $N$ Engl J Med 374: $33-42$.

Villa LL, Costa RL, Petta CA, Andrade RP, Ault KA, Giuliano AR, Wheeler CM, Koutsky LA, Malm C, Lehtinen M, et al. 2005. Prophylactic quadrivalent human papillomavirus (types $6,11,16$, and 18) $\mathrm{L} 1$ virus-like particle vaccine in young women: A randomised double-blind placebocontrolled multicentre phase II efficacy trial. Lancet Oncol 6: 271-278.

Wilson NA. 2006. Vaccine-induced cellular immune responses reduce plasma viral concentrations after repeated low-dose challenge with pathogenic simian immunodeficiency virus SIVmac239. J Virol 80: 5875-5885.

Wong G, Richardson JS, Pillet S, Patel A, Qiu X, Alimonti J, Hogan J, Zhang Y, Takada A, Feldmann H, et al. 2012. Immune parameters correlate with protection against Ebola virus infection in rodents and nonhuman primates. Sci Transl Med 4: 158ra146.

Xiao X, Chen W, Feng Y, Dimitrov DS. 2009a. Maturation pathways of cross-reactive HIV-1 neutralizing antibodies. Viruses 1: 802-817.

Xiao X, Chen W, Feng Y, Zhu Z, Prabakaran P, Wang Y, Zhang MY, Longo NS, Dimitrov DS. 2009b. Germlinelike predecessors of broadly neutralizing antibodies lack measurable binding to HIV-1 envelope glycoproteins: 


\section{H. Golding et al.}

Implications for evasion of immune responses and design of vaccine immunogens. Biochem Biophys Res Commun 390: 404-409.

Yates NL, Liao HX, Fong Y, deCamp A, Vandergrift NA, Williams WT, Alam SM, Ferrari G, Yang ZY, Seaton KE, et al. 2014. Vaccine-induced Env V1-V2 IgG3 correlates with lower HIV-1 infection risk and declines soon after vaccination. Sci Transl Med 6: 228ra239.

Yuan T, Li J, Zhang Y, Wang Y, Streaker E, Dimitrov DS, Zhang MY. 2011. Putative rhesus macaque germline pre- decessors of human broadly HIV-neutralizing antibodies: Differences from the human counterparts and implications for HIV-1 vaccine development. Vaccine 29: 6903-6910.

Zolla-Pazner S, deCamp A, Gilbert PB, Williams C, Yates NL, Williams WT, Howington R, Fong Y, Morris DE, Soderberg KA, et al. 2014. Vaccine-induced IgG antibodies to V1V2 regions of multiple HIV-1 subtypes correlate with decreased risk of HIV-1 infection. PLoS ONE 9: e87572. 


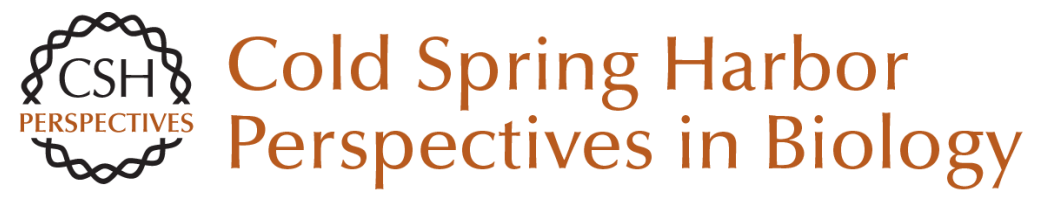

\section{What Is the Predictive Value of Animal Models for Vaccine Efficacy in Humans?: The Importance of Bridging Studies and Species-Independent Correlates of Protection}

Hana Golding, Surender Khurana and Marina Zaitseva

Cold Spring Harb Perspect Biol 2018; doi: 10.1101/cshperspect.a028902 originally published online March 27, 2017

Subject Collection Immune Memory and Vaccines: Great Debates

Is There Natural Killer Cell Memory and Can It Be Harnessed by Vaccination?: Can Natural Killer and CD8 T Cells Switch Jobs?

Christine A. Biron and Marcus Altfeld

Is There Natural Killer Cell Memory and Can It Be Harnessed by Vaccination?: Vaccination Strategies Based on NK Cell and ILC Memory Megan A. Cooper, Todd A. Fehniger and Marco Colonna

Is It Possible to Develop Cancer Vaccines to Neoantigens, What Are the Major Challenges, and How Can These Be Overcome?: Neoantigens as Vaccine Targets for Cancer Haydn T. Kissick

Is It Possible to Develop Cancer Vaccines to Neoantigens, What Are the Major Challenges, and How Can These Be Overcome?: Neoantigens: Nothing New in Spite of the Name

Olivera J. Finn and Hans-Georg Rammensee
Is There Natural Killer Cell Memory and Can It Be Harnessed by Vaccination?: NK Cell Memory and Immunization Strategies against Infectious Diseases and Cancer Joseph C. Sun and Lewis L. Lanier

Is There Natural Killer Cell Memory and Can It Be Harnessed by Vaccination?: Natural Killer Cells in Vaccination

Harold R. Neely, Irina B. Mazo, Carmen Gerlach, et al.

Is It Possible to Develop Cancer Vaccines to Neoantigens, What Are the Major Challenges, and How Can These Be Overcome?: Targeting the Right Antigens in the Right Patients Stephen P. Schoenberger

Which Dengue Vaccine Approach Is the Most Promising, and Should We Be Concerned about Enhanced Disease after Vaccination?: There Is Only One True Winner Scott B. Halstead

For additional articles in this collection, see http://cshperspectives.cshlp.org/cgi/collection/

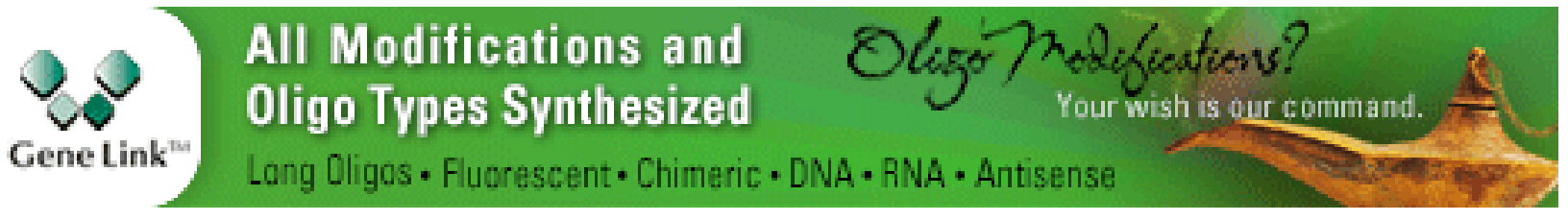


Which Dengue Vaccine Approach Is the Most Promising, and Should We Be Concerned about Enhanced Disease after Vaccination?: The Challenges of a Dengue Vaccine

Gavin Screaton and Juthathip Mongkolsapaya

Which Dengue Vaccine Approach Is the Most Promising, and Should We Be Concerned about Enhanced Disease after Vaccination?: The Path to a Dengue Vaccine: Learning from Human Natural Dengue Infection Studies and Vaccine Trials Aravinda M. de Silva and Eva Harris

Is It Possible to Develop a "Universal" Influenza Virus Vaccine?: Potential for a Universal Influenza Vaccine James E. Crowe, Jr.

Is It Possible to Develop a "Universal" Influenza Virus Vaccine?: Outflanking Antibody Immunodominance on the Road to Universal Influenza Vaccination

Davide Angeletti and Jonathan W. Yewdell
Which Dengue Vaccine Approach Is the Most Promising, and Should We Be Concerned about Enhanced Disease after Vaccination?: Questions Raised by the Development and Implementation of Dengue Vaccines: Example of the Sanofi Pasteur Tetravalent Dengue Vaccine Bruno Guy

Which Dengue Vaccine Approach Is the Most Promising, and Should We Be Concerned about Enhanced Disease after Vaccination?: The Risks of Incomplete Immunity to Dengue Virus Revealed by Vaccination

Stephen S. Whitehead and Kanta Subbarao

Is It Possible to Develop a "Universal" Influenza Virus Vaccine?: Immunogenetic Considerations Underlying B-Cell Biology in the Development of a Pan-Subtype Influenza A Vaccine Targeting the Hemagglutinin Stem Sarah F. Andrews, Barney S. Graham, John R. Mascola, et al.

Is It Possible to Develop a "Universal" Influenza Virus Vaccine?: Potential Target Antigens and Critical Aspects for a Universal Influenza Vaccine Florian Krammer, Adolfo García-Sastre and Peter Palese

For additional articles in this collection, see http://cshperspectives.cshlp.org/cgi/collection/

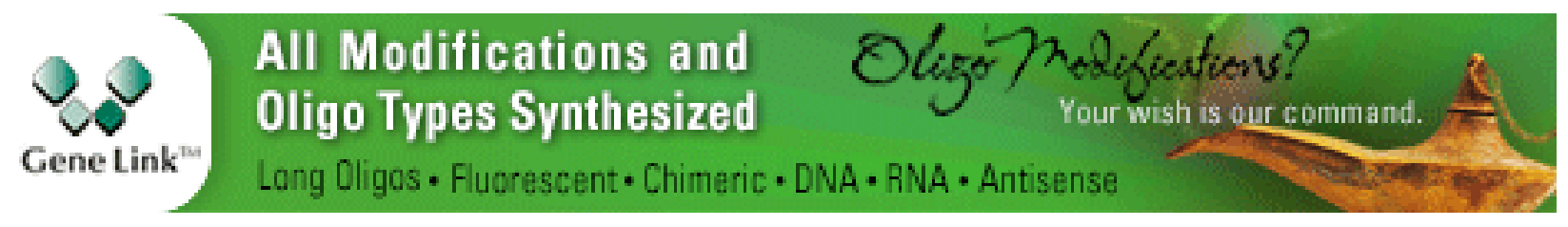

